\title{
Environmental and Economic Benefits of Slow Steaming
}

\author{
Marina Zanne, Milojka Počuča, Patricija Bajec
}

Notwithstanding the fact that maritime shipping is the most energy efficient mode of transportation for large quantities of freight, there are continues efforts to improve its performance. These efforts have become even more intensive since the beginning of global economic crisis.

Slow steaming is one of the attempts to improve both environmental and economic performance of maritime shipping.

The paper gives an overview of existing studies on slow steaming and lists other available and already applicable solutions.

\section{KEY WORDS:}

$\sim$ Slow steaming

$\sim$ Operating costs

$\sim$ Environmental efficiency

$\sim$ Maritime transport efficiency
University of Ljubljana, Faculty of Maritime Studies and Transport

e-mail: marina.zanne@fpp.uni-lj.si

milojka.pocuca@fpp.uni-lj.si

patricija.bajec@fpp.uni-lj.si

\section{INTRODUCTION}

International trade largely depends on maritime transportation as around $80 \%$ of the global trade by volume and over $70 \%$ by value is carried by sea and is handled by ports worldwide (Panitchpakdi, 2013).

The world fleet consisted of more than 104 thousands of merchant ships at the beginning of January, 2012 (RMT, 2012, p. 34). These ships in general use bunkers which are, by definition, made up mostly from residual fuel oil (Drewery, 2006, p. 142). When burned, these oils produce large amounts of sulphur oxides $\left(\mathrm{SO}_{\mathrm{x}}\right)$, nitrogen oxides $\left(\mathrm{NO}_{\mathrm{x}}\right)$, carbon dioxide $\left(\mathrm{CO}_{2}\right)$, carbon monoxide (CO), particulate matters (PM), volatile organic compounds (VOCs), etc.

There have been many technical and operational solutions identified to reduce fuel consumption and consequently harmful emission from shipping industry, however it seems that so far slow steaming has become most widely accepted by the shipping carriers. One of the reasons for this is because fuel usage costs make up $50-70 \%$ of a ship's total operating expense, and with volatile fuel prices can represent an unpredictable expenditure to maritime companies (Emerson, 2013, p. 2).

Slow steaming indicates a reduction of operating speed of long-distance liner ships. It is mainly applied in container shipping. There are several levels of slow steaming; "slow steaming" for reduction of about $15 \%$ with regard to the normal operating speed; "extra slow steaming" for reduction of about $25 \%$, and "super slow steaming" for even higher reductions in operating speed.

The objective of the paper is to present pros and cons of slow steaming identified by the existing studies as well as to give an overview of possible alternative approaches towards costs and emissions reduction in maritime shipping. 


\section{TWO ASPECTS OF ONE PROBLEM - THE INCREASING FUEL CONSUMTION IN INTERNATIONAL SHIPPING}

Maritime transportation is supporting international trade for thousands of years. The trade has in general a growing trend, and maritime industry responds with the increasing ordering of ever larger ships; in January 2012 the merchant fleet of almost than 105 thousands of ships had more than 1.5 billion deadweight (DWT) tonnage, and these ships these ships transported 8,748 million tons of cargo in 2011.

However, international trade is growing slower than the DWT capacity, in particular since the pre-crisis year 2007, and this is resulting in oversupply of capacity and consequently in lower utilization of individual ship in average as can be seen from Table 1.

Table 1.

Tons of cargo carried per deadweight ton.

Source: Authors, based on RMT, 2012, p. 6, p. 34, RMT, 2009, p. 38 and RMT, 2001, p. 25

\begin{tabular}{llll} 
& $\begin{array}{l}\text { Trade } \\
\text { (million tons) }\end{array}$ & $\begin{array}{l}\text { DWT } \\
\text { (million tons) }\end{array}$ & Coefficient \\
\hline 2011 & 8,748 & 1,534 & 5.70 \\
\hline 2010 & 8,409 & 1,396 & 6.02 \\
\hline 2009 & 7,858 & 1,276 & 6.16 \\
\hline 2008 & 8,229 & 1,192 & 6.90 \\
\hline 2007 & 8,034 & 1,118 & 7.19 \\
\hline 2006 & 7,700 & 1,043 & 7.38 \\
\hline 2005 & 7,109 & 960 & 7.41 \\
\hline 2000 & 5,984 & 799 & 7.49 \\
\hline & & & \\
\hline
\end{tabular}

The demand for fuel is increasing in international shipping as it can be seen in Table 2 .

Table 2.

Fuel consumption (million tons) in international shipping. Source: IMO, 2009, p. 37

\begin{tabular}{llll} 
& Low bound & Consensus & High bound \\
\hline 1990 & 120 & 149 & 185 \\
\hline 1995 & 141 & 176 & 218 \\
\hline 2000 & 166 & 206 & 256 \\
\hline 2005 & 204 & 253 & 314 \\
\hline 2006 & 215 & 267 & 331 \\
\hline 2007 & 223 & 277 & 344 \\
\hline
\end{tabular}

Fuel consumption and, consequently, bunker costs depend mainly on ship's speed, but also on ship's design and hull condition as well as bunker fuel grade, weather conditions, etc. But, bunker costs significantly depend also on bunker price, which is an external factor and out of control for ship operators. In ocean shipping, bunker fuel prices have more than quadrupled in the last decade, from about \$170/metric ton in 2000 (Ballou, 2013). In fact, according to the latest data from Bunkerworld (2013), the fuel prices range from around $\$ 600$ for IFO 380 to more than $\$ 1,000$ for MGO at main bunker points.

Slow steaming can help economic performance of shipping carrier in two ways: it can artificially decrease the supply in maritime transportation, so shipping carriers can benefit from lower fuel consumption as well as from higher freight rates due to better relation between supply and demand.

Fuel consumption is closely related to the harmful emissions. Although maritime transportation is clean and energy efficient mode of transportation (see Figure 1), emissions from the growing maritime transport sector represent a significant and increasing air pollution source (Miola et al., 2009, p. 25).

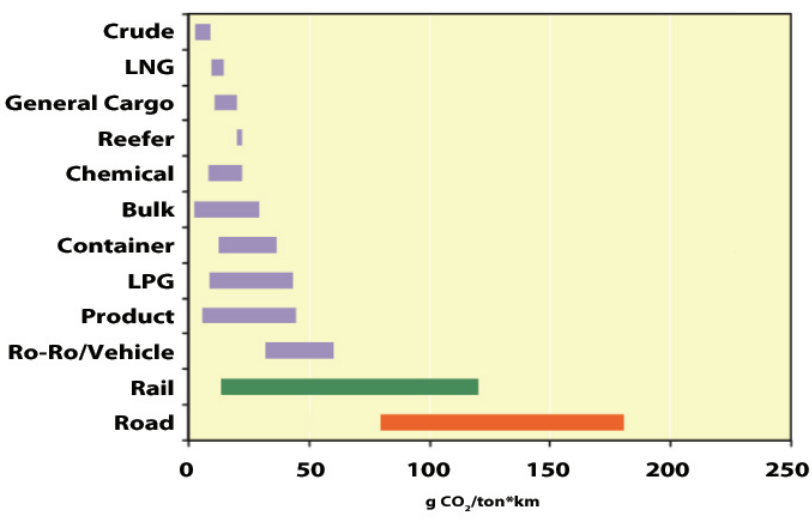

Figure 1.

$\mathrm{CO}_{2}$ efficiencies of ships compared with rail and road transport.

Source: (IMO, 2009, p. 9)

There's an estimation that international shipping emitted 870 million tons of $\mathrm{CO}_{2}$ in 2007, which was around $2.7 \%$ of the global total of that year, but mid-range scenarios show that by 2050 those emissions could grow by a factor of 2 to 3 if no regulations to stem them are enacted (IMO, 2009, p.1). In addition exhaust emissions from international shipping included also 20 million tons of $\mathrm{NO}_{\mathrm{x}^{\prime}} 12$ million tons of $\mathrm{SO}_{\mathrm{x}^{\prime}} 1.5$ million tons of $\mathrm{PM}$ and 2 million tons of CO (IMO, 2009, p. 28). 
By averaging the air pollution cost factors obtainable from the study on External Costs of Transport in Europe (CD Delft, 2011, p. 38, p. 45) we can estimate the external costs of international shipping to be around 330 billion EUR in $2007^{1,2}$.

Corbett and others point towards the dangers arising from maritime transportation that affect human population. They say that shipping related particulate matters (PM) emissions are responsible for approximately 60,000 cardiopulmonary and lung cancer deaths worldwide annually, with most deaths occurring near coastlines in Europe, East Asia and South Asia. Under current regulation and with the expected growth in shipping activity, they estimated that annual mortalities could increase by $40 \%$ by 2012 (Corbett et al., 2007, p. 8512).

This is because (IMO, 2009, p. 12):

- $\quad 70 \%$ of maritime traffic occurs within 200 nautical miles from shore,

- $44 \%$ of maritime traffic occurs within 50 nautical miles from shore and

- $36 \%$ of maritime traffic occurs within 25 nautical miles from shore.

With respect to GHG, substantial efforts were taken to develop technical (mainly applicable to new ships, e.g. Energy Efficiency Design Index - EEDI), operational (applicable to all ships, e.g. Ship Energy Efficiency Management Plan - SEEMP and Energy Efficiency Operational Indicator - EEOI) and financial measures (e.g. carbon price for shipping) to regulate GHGs, in particular $\mathrm{CO}_{2}$, emissions from shipping. Consequently, in July 2011 all these measures were adopted into a new chapter in MARPOL Annex VI.

\section{PAST STUDIES}

Slow steaming is not a new approach to reduce fuel costs; in fact, it was for the first time in use in 1970s during the first oil crisis. However, slow steaming has now a double effect: cutting costs and cutting harmful emissions from maritime transportation. Studies show that when a ship reduces its speed by $10 \%$, its engine power is reduced by $27 \%$ (Faber et al., 2012, p. 7). A $10 \%$ reduction in fleet average speed results in a $19 \%$ reduction of $\mathrm{CO}_{2}$ emissions even after accounting for the emissions of additional ships needed to deliver the same amount of transport work and the emissions associated with building the necessary additional ships. Emissions of $\mathrm{SO}_{x^{\prime}} \mathrm{NO}_{\mathrm{x}}$ and probably black carbon will decrease in line with fuel use and $\mathrm{CO}_{2}$ emissions (Dings, 2012, p. 6). According to previously given estimation of external costs of ships' emissions, the reduction of speed by $10 \%$ would result in around $\$ 63$ billion decrease of these costs on yearly basis.

Maersk alone saved around 2 million tons of $\mathrm{CO}_{2}$ in 2010 thanks to slow steaming (Jorgensen, 2012) and turned to a $\$ 639$ million profit in the first three months of 2010 from a $\$ 373$ million loss in the same period of 2009 (Tidetech news, 2012). For example: Running a 10,000 TEU containership at 18-20 knots instead of the optimal cruising speed of 20-25 knots, can deliver daily savings of 175 tonnes of bunkers. Moreover, super-slow steaming at 15-18 knots improves the picture even further, saving an additional 100 tonnes per day (Wackett, 2013).

The survey carried out by MAN PrimeServ in late 2011 revealed that engine retrofit, derating and propeller upgrade measures delivered fuel savings either as expected or higher than expected (MAN, 2012, p. 4).

From the economic point of view of a shipping carrier, it is thus necessary to find an optimal speed to have total costs reduced to minimum. But this is feasible in economic sense only when maritime market is in depression. There is, hence, an expectation that, as the economy and markets pick up and excess capacity is brought back into service, speeds will increase again to meet the growing demand (Dings, 2012, p. 4).

There are other entities besides shipping carriers involved in the supply chain, and the question is how they accept the slow steaming. Longer transit times can actually increase shippers' costs because they need more inventory to feed this longer supply chain. Longer ocean transit times can also impact shippers' cash flow as the time from production to sale is extended (Kloch, 2013).

But, the MAN PrimeServ survey documented a positive reaction to slow steaming by a large majority of the global shipping community (Table 3 ).
1, 2 The first IMO study on greenhouse gas (GHG) provided estimation that ships engaged in international trade contributed about 1.8 per cent of the world total anthropogenic CO2 emissions in 1996.

Expressed in prices of 2008, and excluding cost estimation for CO and VOC emissions.
3. Those measures are needed to make slow steaming technically impeccable. 
Table 3.

Customer reactions to slow steaming [\%].

Source: MAN, 2012, Slow Steaming Practices in the Global Shipping Industry, p. 7

\section{Considerers Implementers}

\begin{tabular}{|c|c|c|}
\hline $\begin{array}{l}\text { Positive, without } \\
\text { reservation }\end{array}$ & 18.0 & 32.4 \\
\hline $\begin{array}{l}\text { Positive, as long as } \\
\text { schedule reliability is } \\
\text { not impacted }\end{array}$ & 35.1 & 29.7 \\
\hline $\begin{array}{l}\text { Positive, as long as it } \\
\text { means lower rates }\end{array}$ & 15.3 & 10.8 \\
\hline $\begin{array}{l}\text { Indifferent, as long as } \\
\text { schedule reliability is } \\
\text { not impacted }\end{array}$ & 5.4 & 8.1 \\
\hline $\begin{array}{l}\text { Negative, because of } \\
\text { destination logistics } \\
\text { planning }\end{array}$ & 3.6 & 2.7 \\
\hline $\begin{array}{l}\text { Negative, because of } \\
\text { sensitive or perishable } \\
\text { cargo }\end{array}$ & 0 & 0 \\
\hline Do not know & 22.5 & 13.5 \\
\hline
\end{tabular}

For many manufacturers, retailers, importers and exporters, supply chain reliability is, thus, more important than transit time or rates (Kloch, 2013), and slow steaming gives better time flexibility than regular steaming as there is still space for speed increase if the ship is in delay.

Similar confirmation to slow steaming is given by the study Smarter Steaming Ahead which states that if the direct costs (fuel use, crew, capital costs of ships), indirect costs (additional inventory costs, adjustment of logistic chains) and external costs (impacts of emissions on human health and ecosystems, climate impacts) are taken into account, the benefits of slow steaming outweigh the costs (Dings, 2012, p. 6).

However, it is very difficult to predict the effect of slow steaming on individual shipper as it depends on many factors (Kloch, 2013): from product type and volumes to credit facilities and insurance terms, as well as destination and customer expectations.

\section{ALTERNATIVE APPROACHES}

There are many other ways, besides slow steaming to reduce fuel consumption, such as (Hochkirch \& Bertram, 2010):

- Reduce required power for propulsion,

- Reduce required power for equipment on board,

- Substitute fuel power (partially) by renewable energies like wind and solar energy.
Waste heat recovery systems are already in use on merchant ships, and alternative operating systems have recently started being installed and tested.

The kite ship or the skysail technology has been proved to reduce fuel consumption of ships when the kite is used in strong winds. Aghina Marina - the largest bulk carrier ship to use skysail technology and Beluga Skysail are some examples wherein the kite technology has been used successfully (Kantharia, 2013).

Nichioh Maru Car Carrier is an eco-friendly ship partially fuelled by solar power. This unique engineering system helps the vessel to reduce nearly 1,400 tonnes of exhaust discharges. This accounts for an estimated reduction in carbon dioxide discharges by over 4,000 tonnes yearly (Sharda, 2013).

MV Hallaig is the first passenger/vehicle Ro-Ro ferry in the world to be equipped with a multi-fuelling system using dieselelectricity and lithium ionized battery systems. This also makes it the world's first hybrid ferry (Wankhede, 2013).

In future, ships might be fuelled by Liquefied Natural Gas (LNG), an environmentally friendly, safe, and widely available and thus low-cost alternative to current heavy oil fuels.

\section{CONCLUSIONS}

Slow steaming is not the only way of reducing fuel consumption and, therefore, fuel costs and harmful emissions, but it seems to be the least time and money consuming and, thus, widely accepted by shipping carriers around the world. In fact, this approach has many advantages as it can be seen in Table 4. This has been recongnized both from the shipping carriers that have already implemented the necessary technology and from those still considering that option.

Table 4.

Main advantages of slow steaming as perceived by considerers and implementers [\%].

Source: MAN, 2012, Slow Steaming Practices in the Global Shipping Industry, p. 5

\section{Considerers Implementers}

[\%] [\%]

\begin{tabular}{lll}
\hline Fuel cost savings & 93.7 & 94.7 \\
\hline $\begin{array}{l}\text { Greater utilisation of } \\
\text { existing capacity }\end{array}$ & 22.5 & 34.2 \\
\hline $\begin{array}{l}\text { Avoidance of idling } \\
\text { costs }\end{array}$ & 29.7 & 28.9 \\
\hline $\begin{array}{l}\text { Schedule reliability } \\
\text { Service and }\end{array}$ & 10.0 & 15.8 \\
maintenance savings & 17.1 & 18.4 \\
\hline \begin{tabular}{l} 
Lower emissions \\
\hline
\end{tabular} & 36.0 & 42.1 \\
\hline
\end{tabular}


As different studies show, majority of customers have positively accepted slow steaming, although some individual customers might lose their market position due to longer delivery times and costs connected to this.

Alternative approaches do not affect the operating speed of the ship as slow steaming does, and many believe that slow steaming could be refused as soon as maritime market recovers, or can become regulated if external benefits are recognized in their entirety.

The future of slow steaming will mostly rely on market situation, fuel prices as well as on the supply chain requirements and the oscillations in vessel's operating cost. Considering the fact that the environmental concerns will not vanish, but instead might then become even more emphasized, slow steaming will probably not be an optimal solution when global economy revives.

\section{REFERENCES}

Ballou, P. J., (2013), Ship Energy Efficiency Management Requires a Total Solution Approach, Marine Technology Society Journal, 47(1), pp. 83-95., http://dx.doi.org/10.4031/MTSJ.47.1.5

Corbett, J. J., Winebrake, J. J., Green, E. H., Kasibhatla, P., Eyring, V. and Lauer, A., (2007), Mortality from ship emissions: a global assessment, Environmental Science \& Technology, 41(24), pp. 8512-8518., http://dx.doi.org/10.1021/es071686z

Dings, J., (2012), Smarter Steaming Ahead. Brussels: Seas At Risk and Transport \& Environment.

Faber, J., Nelissen, D., Hon, G., Wang, H. and Tsimplis, M., (2012), Regulated Slow Steaming in Maritime Transport: An Assessment of Options, Costs and Benefits. Delft: CE Delft.

Group of authors, (2011), External Costs of Transport in Europe (Update Study for 2008). Delft: CE Delft.

Group of authors, (2009), Second IMO GHG Study 2009. London: International Maritime Organization.

Hochkirch, K. and Bertram, V., (2010), Options for Fuel Saving for Ships. Mare Forum USA 2010: Maritime Transportation of Energy. Houston, USA, February 19, available

http://www.mareforum.com/ENERGY_TRANSPORTATION_USA_2010_PAPERS/ HOCHKIRCH_paper.pdf, [accessed 1 August 2013.].
Jorgensen, R., (2012), Slow Steaming: The Full Story. Copenhagen: Maersk.

Kantharia, R., (2013), Top 7 Green Ship Concepts Using Wind Energy, available at: http://www.marineinsight.com/ marine/marine-news/headline/top-7-green-shipconcepts-using-wind-energy/, [accessed 5 August 2013.].

Kloch, L., (2013), Is Slow Steaming Good for the Supply Chain?, available at: http:// www.inboundlogistics.com/cms/ article/is-slow-steaming-good-for-the-supplychain/, [accessed 3 August 2013.].

Miola, A. et al., (2009), External costs of transportation - Case study: Maritime transport. Ispra: JRC.

Panitchpakdi, S., (2013), Review of Maritime Transport 2012, available at: http:// unctad.org/en/pages/ PublicationWebflyer.aspx?publicationid=380, [accessed 1 August 2013.].

RMT, (2008), Review of Maritime Transport 2008. Division on Technology and Logistics, New York and Geneva: UNCTAD.

RMT, (2008), Review of Maritime Transport 2008. Division on Technology and Logistics, New York and Geneva: UNCTAD.

RMT, (2012), Review of Maritime Transport 2012. Division on Technology and Logistics, New York and Geneva: UNCTAD.

Sharda, (2013), Nichioh Maru - The First Car Carrier with Solar Power System, available at: http://www.marineinsight. com/marine/marine-news/headline/ nichioh-maru-the-first-car-carrier-with-solar-power-system/, [accessed 5 August 2013.].

Unknown, (2012), Slow steaming speeds up, available at: http://www.tidetech.org/ news/Slow_steaming_speeds_up.html, [accessed 4 August 2013.].

Unknown author, (2006), Ship management. London: Drewery Shipping Consultants Itd.

Unknown, (2013), Marine Fuel Measurement - Superior measurement for outstanding results. Boulder: Micro Motion.

Unknown author, (2012), Slow Steaming Practices in the Global Shipping Industry. Copenhagen: MAN PrimeServ.

Unknown, (2013), Bunker prices, available at: http://www.bunkerworld.com/prices/, [accessed 11 August 2013.].

Wackett, M., (2013), Lower speeds boost box schedule reliability, say top European customers. LLoyd's List.

Wankhede, A., (2013), The World's First Hybrid Ferry - MV Hallaig, available at: http:// www.marineinsight.com/marine/marine-news/headline/the-worlds-first-hybridferry-mv-hallaig/, [accessed 5 August 2013.]. 